\title{
Economic potentials of artisanal food processing microenterprises in West Africa: case of "atta" production in Cotonou (Benin)
}

\author{
Claudia E. Kpossilande ${ }^{1}$, Barthélemy G. Honfoga ${ }^{1 *}$ (D) and Thierry Ferre ${ }^{2}$
}

\author{
*Correspondence: honfogabg@ \\ yahoo.fr \\ ${ }^{1}$ Faculty of Agronomic Sciences, \\ University of Abomey Calavi, 03 BP \\ 2819 Jericho, Cotonou, Benin \\ Full list of author information is \\ available at the end of the article
}

\begin{abstract}
Rapid population growth and urbanization in West Africa have led to profound changes in the lifestyles and diets of urban dwellers. These changes are marked by greater preference for healthier and more nutritious foods, easy to prepare and to consume while saving time. Hence, the development of small-scale food processing and catering activities in the cities. However, despite its importance, the urban food industry still faces several constraints, mainly the lack of equipment that would save cooking time and increase the nutritional quality of final products for consumers. Promoting optimum food processing technologies and business processes has therefore become a major concern for research and policy-makers. This study was conducted as part of the ICOWPEA research project aimed at assessing the economic and sales potential of artisanal food processing microenterprises that produce "atta," a cowpea fritter or snack, in the city of Cotonou. A sample of twentyseven women-headed microenterprises was randomly selected from a list of 125 recorded in 22 streets distributed across 13 districts of the city. They were interviewed using a structured questionnaire. The survey allowed us to assess how they function, their production costs, and financial performance. The surveyed microenterprises belonged to woman artisans, average age 45, who ran their own businesses. Microenterprises allow many young family members to enter the informal job market. While knowledge is mostly transmitted from mother to daughter and based on learning by doing, very simple processing tools are used. Although mechanical milling is used at some stages of cowpea processing, overall, artisanal "atta" production is a low-profitability business with a return rate of only $11.7 \%$. However, it contributes to feeding the family and rewards family labor that accounts for up to $27.6 \%$ of total production cost. In addition to creating jobs for low-income female youth, the activity accounts for a remarkable share of the urban food business sector in Cotonou. Technological upgrading and business empowerment are required for these women to become real entrepreneurs and to overcome the key constraints they face, including the lack of access to credit and absence of improved technologies, training and government recognition. In that respect, appropriate policies are needed to take them out of poverty and make (Continued on next page)
\end{abstract}


(Continued from previous page)

Benin the emerging economy it aspires to be. In particular, a dedicated investment and business development support scheme is required to better meet the growing domestic urban food demand and, in the near future, to envisage the export of stabilized and safer finished cowpea products.

Keywords: Cowpea, "Atta" snacks, Female artisans, Microenterprises, Women, Food processing, Economic performance, Urban poverty reduction

\section{Introduction}

Rapid urbanization and population growth have led to profound changes in the lifestyles and diets of West African populations (Honfoga et al. 2018). Urban food demand has increased in parallel, thereby exerting strong pressure on infrastructure and transport that is already inadequate and in poor condition. The situation is forcing many urban dwellers to turn to outdoor catering (Staatz and Hollinger 2016; Agli et al. 2004). Households are increasingly buying from markets and are turning to more diversified diets, but also to easy-to-cook and highly palatable meals (Allen et al. 2018). These developments, which affect all countries of the sub-region as well as all income groups, have increased the consumption of processed, high value-added foods derived from perishable agricultural products (Reardon 2015; Staatz and Hollinger 2016; Allen and Heinrigs 2016). Hence, the development of small-scale food processing and catering activities, referred to as "street food," "snacks," or "popular restaurants" (Allen et al. 2018, Bendech 2013; FAO 1997), together defined as the "sector producing food and beverages ready for consumption, prepared and/or sold by vendors, especially in the streets and other similar public places" (FAO 1997).

The food economy is the largest employer in the West African region and will continue to offer many opportunities with increasing population and urbanization, and rising incomes. In seven West African countries (Ghana, Burkina Faso, Mali, Nigeria, Niger, Ivory Coast, Senegal), the share of women's employment is on average $51 \%$ throughout the economy but significantly higher, reaching $83 \%$ in the food processing and $88 \%$ in catering sectors (Allen et al. 2018). Food processing is dominated by artisanal food and concerns all food groups including cereals, roots and tubers, legumes, oilseeds, fruits, meat and fish, dairy products, and condiments. In cities, it plays an important role in the daily lives of thousands of people, both as a means of food security and as a source of employment and income (Allen et al. 2018; Broutin and Rouyat 2008, Agli et al. 2004). It helps increase food availability by processing raw farm products, making it possible to reduce postharvest losses and prolong food shelf life (Bricas and Broutin 2008). It also enables a supply of low-cost food and income flows to the urban poor.

The development of the food economy, and more particularly that of small-scale food processing, is quite recent in West Africa. For a long time, food processing was only based on empirical knowledge and know-how, most often in the form of nonmechanized and non-standardized processing by rural households for their own consumption (Trèche et al. 2002). Despite its importance in the urban economy, artisanal food processing still faces several constraints: activities in the sector are not recognized as "real businesses" and are therefore not taken into account in public policies. Family labor accounts for a large proportion of total labor costs in these informal and 
unrecognized economic activities, but are not recorded by peasant/small-scale farmers in their farm budgets or operating accounts (Mayer and Glabe 2008), or by the producers of processed foods themselves. More strikingly, the depreciation of equipment used in low-productivity artisanal food processing is simply ignored by woman artisans when they assess the profit of their microenterprises.

The artisanal food sector also faces structural problems, including limited professional structuring, very low investment capacity, and poor food hygiene (Dossou et al. 2017, Bricas and Broutin 2008, Broutin and Rouyat 2008, Agli et al. 2004). Artisanal food processing is mostly informal and plagued by poverty. Targeted policies are required to address these constraints in order to increase the sector's added value to the countries' economy and to bring it into the line with its high contribution to employment.

Here, we investigate artisanal cowpea-processing microenterprises in Cotonou, the capital of Benin, with a focus on the production of "atta", a cowpea fritter, or deepfried dumpling also called "Akara" in Nigeria or "Koose" in Ghana (Madode et al. 2011). It is one of the most widespread forms of cowpea consumption in West Africa (Robinson et al. 2014; Madode 2012; CESAO-PRN 2009; Doka 2010). It is a traditional snack resembling "Acarajé" in Brazil, but its texture is thinner, and its size is smaller like meatballs. In Cotonou and many urban centers, it is sold to consumers in smaller portions that cost between two and five US dollar cents each.

To date, artisanal cowpea-based products, as well as other processed foods sold in local markets, are ignored in policy debates and studies on the topic are rare in the literature. Yet, it is hypothesized that the production of "atta" and other cowpea-derived products could boost the development of cowpea value chains, as has been the case with other local food crops undergoing artisanal food processing.

Although "atta" production has already been shown to be an important source of income for hundreds of microenterprises run by women in Cotonou, its profitability and overall performance remain to be demonstrated. The aim of this study was thus to assess the economic performance (production cost, added value, and profitability) of these microenterprises and their potential to provide employment and an income for female youth in Benin. From the perspective of becoming an emerging economy to which Benin aspires, we also discuss the capacity of these craftswomen to emerge from a subsistence and poverty reproduction business, in order to capture rapidly evolving urban markets. These markets are characterized by increasing demand for quality food, time-saving meal preparation and consumption, and growing competition from imported manufactured products. Honfoga et al. (2018) pointed out that modern or improved processing technologies are key to generating quality food products and tend to drive urban consumers' preferences for imported/introduced foods over traditional foods.

\section{Methodology}

Data collection

The study was conducted in 22 streets, representing $15 \%$ of the 144 streets that make up Cotonou city (Fig. 1). This sampling ratio was applied to each of the 13 boroughs in the city to determine the number of streets to be selected. In each borough, the streets were chosen randomly. The unit of observation and analysis is one "atta" production microenterprise. 


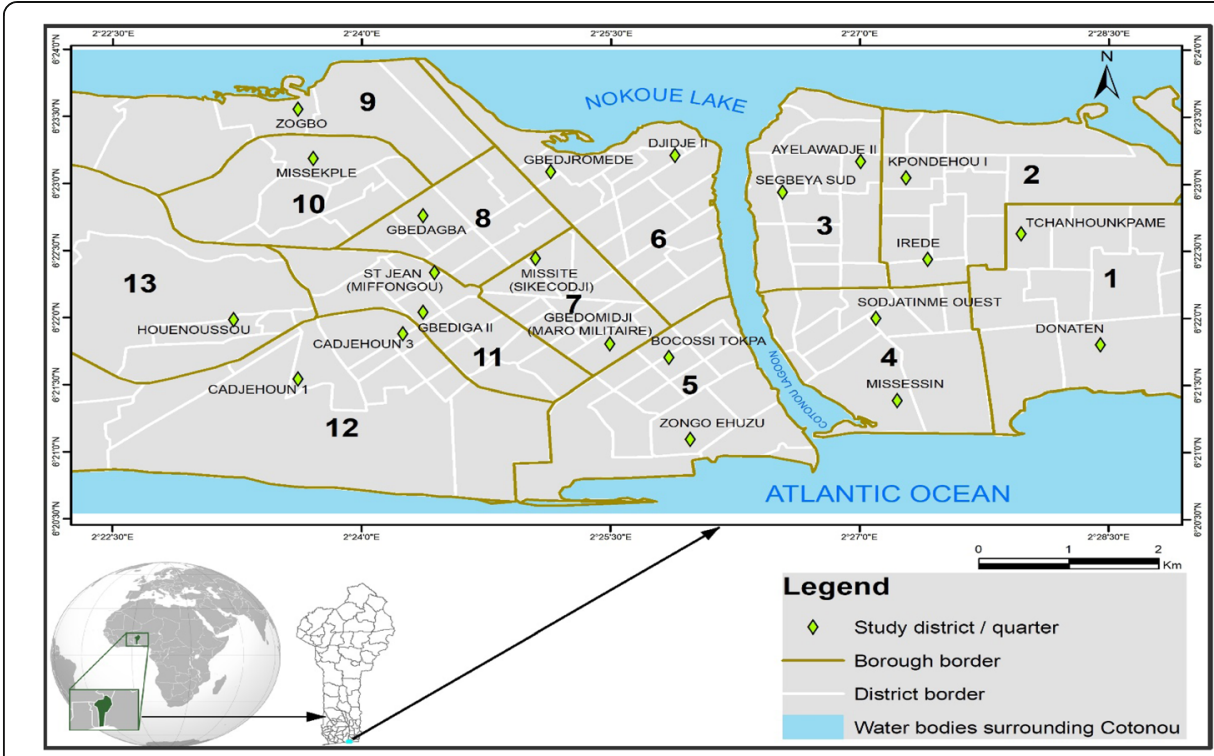

Fig. 1 Location of the streets of sample "atta" microenterprises in the city of Cotonou. Source: Map by Evrard AKPLA with survey data provided by Claudia Kpossilande

Data were collected in two stages between September and December 2017. During the first exploratory stage, all cowpea processing units that produce "atta" in the 22 selected streets were identified. Using semi-structured interview guides, group discussions and interviews were conducted with a few woman artisans and other resource persons. The second stage consisted of an interview using a detailed questionnaire with 27 woman artisans randomly selected from a census list of 125 processing microenterprises. The sampling ratio was therefore $21.6 \%$. Streets with no respondents means no cowpea-processing women were available (Table 1). The data collected include socioeconomic characteristics of the leader of the food microenterprise, work organization and supply of raw materials, information on labor use, the cost of raw materials and intermediate inputs, and the sales price of the final product.

\section{Data processing and analysis}

Quantitative data collected were entered using Microsoft ACCESS software. They were processed and analyzed using Minitab software and the Statistical Package for the Social Science (SPSS). The microenterprises were characterized by computing and interpreting descriptive statistics (frequencies, means, standard deviations) and methods (crosstabs, charts), and financial performance indicators. The analysis of the contents of the qualitative data collected during the exploratory phase (individual and group interviews) was used to describe the processing and marketing operations of the "atta" production microenterprises.

The financial indicators used to assess their economic performance included added value (AV), net operating income (NOI), financial rate of return, and rate of family labor turnover.

Added value (AV) was calculated as the difference between gross revenue (R) and the cost of intermediate inputs (IC). 
Table 1 Geographical distribution and degree of concentration of "atta" production microenterprises in the city of Cotonou

\begin{tabular}{|c|c|c|c|c|c|c|}
\hline Zone & Borough no. & Street name & NA & $\mathrm{NE}$ & $N$ & Ratio N/NA \\
\hline \multirow[t]{14}{*}{ Residential area } & 1 & Donaten & 5 & 0 & 2579 & 516 \\
\hline & 1 & Tchanhounkpame & 6 & 2 & 3894 & 649 \\
\hline & 2 & Irede & 6 & 1 & 4464 & 744 \\
\hline & 2 & Kpondehou I & 9 & 0 & 7233 & 804 \\
\hline & 3 & Segbeya South & 12 & 1 & 6279 & 523 \\
\hline & 3 & Ayelawadje II & 4 & 0 & 7792 & 1948 \\
\hline & 4 & Sodjatinme West & 4 & 0 & 2070 & 518 \\
\hline & 4 & Missessin & 7 & 2 & 2319 & 331 \\
\hline & 6 & Gbedjromede & 7 & 3 & 3255 & 465 \\
\hline & 6 & Djidje ॥ & 6 & 1 & 6588 & 1098 \\
\hline & 8 & Gbedagba & 8 & 0 & 5806 & 726 \\
\hline & 9 & Zogbo & 5 & 2 & 7733 & 1547 \\
\hline & 10 & Missekple & 5 & 1 & 4724 & 945 \\
\hline & 13 & Houenoussou & 3 & 2 & 1266 & 422 \\
\hline \multirow[t]{4}{*}{ Commercial zone } & 5 & Zongo ehuzu & 4 & 0 & 1796 & 449 \\
\hline & 5 & Bocossi tokpa & 5 & 3 & 1154 & 231 \\
\hline & 7 & Gbedomidji (Military Maro) & 4 & 3 & 3188 & 797 \\
\hline & 7 & Missite (SIkecodji) & 6 & 0 & 3466 & 578 \\
\hline \multirow[t]{4}{*}{ Service area } & 11 & Gbediga II & 6 & 0 & 1454 & 242 \\
\hline & 11 & St. Jean (Miffongou) & 3 & 3 & 3298 & 1099 \\
\hline & 12 & Cadjehoun I & 7 & 3 & 3459 & 494 \\
\hline & 12 & Cadjehoun III & 5 & 0 & 1672 & 334 \\
\hline Total & & & 125 & 27 & 85,489 & 684 \\
\hline Percentage (\%) & & & 100 & 21.6 & - & - \\
\hline
\end{tabular}

Source: Survey results, September to December 2017

$N A$ total number of "atta" processing microenterprises counted, NE number of "atta" processing microenterprises surveyed in the study, $\boldsymbol{N}$ population of the street, "-" not relevant

Added value $(\mathrm{AV})=$ gross revenue $(R)$ - intermediate input cost (IC)

Intermediate inputs consisted of raw materials, ingredients used in processing, fuel, packaging (bags, paper, and disposable packages), transport costs, and sales expenses.

Total operating costs included intermediate inputs (IC), occasionally hired labor and family labor cost (LC), financial costs (FC), taxes (TX), and depreciation (D).

Net operating income (NOI) or profit $(P)$ is the income from sales $(R)$ minus total operating cost (TC):

$$
\begin{aligned}
& P=R-\mathrm{TC}=R-\mathrm{IC}-(\mathrm{LC}+\mathrm{FC}+\mathrm{TX}+D) \\
& P=\mathrm{AV}-(\mathrm{LC}+\mathrm{FC}+\mathrm{TX}+D)
\end{aligned}
$$

Profit is the monetary gain (or loss) left to a businessman or agent, after payment of all current operating expenses (Fabre 1994). In other words, it represents the net operating income once all the operating costs are deducted from the gross revenue or annual value of production (see Eq. 3). In standard accounting, the profit of a firm (formally registered business) comprised shareholders' dividends, the statutory annual 
provision for the founder/creator, and the firm's societal reserve or provision for the firm's expansion or liquidation. Informal women's artisanal microenterprises in Benin are not there yet. Mayer and Glabe (2008) clarified the differences between a strict business accounting procedure to establish profits or losses and the procedure that peasants use to evaluate the profitability of cash crops and subsistence crops in Peru. They concluded that money plays an important but perverse role as it cycles through the market and households. They observed that farmers ignore important cash expenses that are necessary to produce subsistence crops whereas they wrongly incorporate government subsidies when evaluating profits from cash crops.

In the present study, we paid particular attention to estimating labor costs when calculating profits. Two types of labor force are used in the artisanal production of "atta": family labor and occasionally hired labor. Family labor is the most frequently used labor force in the majority of cowpea-processing microenterprises. Occasionally hired labor is only used by $3 \%$ of microenterprises. The cost of occasionally hired labor was calculated as the daily wage rate declared by the women who ran the microenterprise we interviewed, whereas family labor cost was estimated as an opportunity cost. The latter was calculated as the declared quantity of that labor force (in man-days) multiplied by the average daily labor wage in the artisanal food processing sector. Opportunity cost and how it was estimated in this study are detailed below.

The opportunity cost corresponds to the remuneration that a self-supplied factor of production would have received if, instead of being devoted to the activity for which it was used, it was used for another activity (Bergmann 1985). It is the reward that would have been gained from the best alternative activity abandoned to undertake it. Based on these definitions, the average opportunity cost of daily family labor in the sector was estimated by referring to recent works in the food economy sector in Benin and neighboring countries.

Yabi et al. (2014) reported that the annual income from agri-food shea processing in north Benin was on average 173,218 FCFA accruing from family labor provided by 4.93 people. The annual income in other activities was 109,319 FCFA. Thus, for 52 weeks/ year and 6 workdays/week, the average remuneration of family labor would be 112.6 FCFA/man-day in shea butter processing and 91.8 FCFA/man-day for all agricultural activities considered together. If we consider the high population density in Cotonou (8593 inhabitants $/ \mathrm{km}^{2}$ in 2013) compared to Parakou (577 inhabitants $\left./ \mathrm{km}^{2}\right)^{1}$ resulting in a higher demand for processed products like "atta" than in the north, the family labor opportunity cost would accordingly be higher. Yet, not everyone in Cotonou consumes traditional food snacks like "atta." We therefore considered the demand for "atta" in Cotonou to be much lower and deliberately estimated the family labor opportunity cost in atta production to be at least 5 times the northern average, i.e., $5 \times 91.8$ FCFA $=459$ FCFA/man-day.

This value is closer to the average labor cost of 428 FCFA/day estimated by Hessanon and Sodssinour (2009) for peeling and washing cassava (470.5 FCFA), pressing (311.4 FCFA), and cooking (502 FCFA) to produce gari in southeastern Benin. It is also comparable to wages uneducated and poor women receive in Cotonou. These women are either involved in petty trade, earning usually 200-500 FCFA as daily profit in the city's suburbs or are employed as a domestic helper and paid an average of 12,500 FCFA/

${ }^{1}$ Source : https://www.ancb-benin.org/Document_pdf/Densite_de_population. 
month, i.e., about 416.7 FCFA/day. But these jobs are not readily available. Recently, in an analysis of cassava value chains in Côte d'Ivoire, (Coulibaly et al. 2014) estimated the monthly remuneration a worker received in 2013 in an "attiéké" cassava-processing enterprise at US\$24.4. If we consider that the company works 6 days a week, the daily remuneration would be US $\$ 24.4 / 24=$ US $\$ 1.02$, i.e., 485.33 FCFA at an exchange rate of US\$1 = 475.82 (December 31, 2013). However, the cost of living in Côte d'Ivoire is higher than in Benin, while producing "attiéké" requires harder work than "atta". Therefore, a lower wage rate should be used. In any case, the average (443.3) of the last three values $(470.5,416.7,485.3)$ is closer to the value of 459 FCFA/man-day we estimated earlier based on Yabi et al. (2014). This value was thus used here as the opportunity cost of family labor for the production of "atta" in Cotonou.

The total number of family workers (FW) in man-equivalents was calculated using a formula from Arouna and Afomasse (2005) as follows:

$\mathrm{FW}=($ number of adult men $)+0.75 \times($ number of adult women $)+0.50$ $\times$ (number of children aged $6-14)$

This formula was adapted from Tshibaka et al. (1992) and Tshibaka (1989) who provided a complete table for calculating the volume of agricultural labor according to gender and to the age categories of workers. We used it, based on the assumption that the realities of the artisanal food processing sector in Cotonou are similar.

The total amount of family labor (AFL in man-days) was calculated by multiplying the number of family workers (FW) by the total duration (Td) of operations (in hours) divided by 8 (number of hours in a workday according to official labor regulations in Benin):

$$
\mathrm{AFL}=\mathrm{FW} \times(\mathrm{Td} / 8)
$$

The rate of return $(\Omega)$ is then determined as the ratio of net operating income (NOI) to total cost (TC).

$$
\Omega(\%)=100 \times \mathrm{NOI} / \mathrm{TC}=100 \times P / \mathrm{TC}
$$

The performance indicators (AV, $P$, and $\Omega$ ) of the "atta"-producing microenterprises were calculated using data on costs and revenues provided by the interviewees for five one-day production cycles. For each cost item, the unit production costs per kilogram of cowpea (per cost item and total) were derived by dividing the weekly costs by the quantity of cowpea processed in a week.

\section{Results and discussion}

The economic analysis of "atta" production by artisanal cowpea-processing microenterprises was performed in three stages: (i) assessment of the concentration of cowpeaprocessing microenterprises in the city, (ii) assessment of the functional characteristics (sites, production systems, work organization, socio-economic characteristics) of the processing units/microenterprises, and (iii) analysis of their financial performance.

\section{Location of "atta" production in the city of Cotonou}

Our survey identified 125 "atta" production microenterprises in 22 selected streets in Cotonou, i.e., an average of six microenterprises per street. The locations of these units 
were examined with respect to the type of location of the street food sales (commercial area, public service area, or residential area), as identified by Agli et al. (2004). Public service and commercial areas are located in the heart of the city while residential areas are located on the outskirts (Agli et al. 2004). The first two zones are areas of high economic activity. The third one is not strictly speaking a "residential area" ${ }^{2}$, in the sense that it does not only comprise luxury dwellings, which is usually the case of a residential area. In this study, it differs from the first two by its high population density and the fact that quite important economic activities take place there too (Table 1).

Comparing the three areas to calculate the average number of workers per "atta" production microenterprise revealed that there is no significant difference between them. This can be explained by the nature of the food, which is a very popular snack consumed in the afternoon break, and its cultural roots in the study environment. Another possible explanation is the intense economic activity in the city, even in areas that are purportedly residential areas. This result is consistent with that of Agli et al. (2004) who found that street food businesses are highly developed in areas of high economic activity with a high population density. However, Madode et al. (2012) found that people with higher incomes, who often live in "real" residential areas, may consume more meat and less cowpea as a source of protein. In addition, the difference in the consumption of cowpea dishes between urban and rural areas may result from the digestive discomfort caused by consuming cowpeas. Therefore, a sharp difference in "atta" business development should have been observed between high-income residential areas and the so-called residential areas in Cotonou. Moreover, the processed foods sold in urban areas are not always produced in adequate hygienic conditions. For example, on the campus of the University of Abomey-Calavi ( $20 \mathrm{~km}$ north of Cotonou), only $50 \%$ of "street restaurants" in the commercial center complied with food hygiene and quality requirements (Honfoga et al. 2019).

Regarding the density of "atta" businesses and job creation, population census data for the study area (Table 1) revealed one "atta" production unit/microenterprise for 684 inhabitants. This made it possible to estimate the number of woman artisans/microenterprises producing atta in the city of Cotonou at more than $3500^{3}$. The number of jobs created is hypothesized to be at least double (7000). It is also worth noting that the market to be satisfied by these atta-producing microenterprises is not limited to Cotonou city residents but also includes the mass of people in the city's suburbs and/or neighboring towns (Abomey, Ouidah, Sème-Kpodji, Porto-Novo, etc.) who come to the city every day for work or other activities.

\section{Functional characteristics of "atta" production cowpea-processing microenterprises}

In this section, we present the characteristics of production and sales, the work organization and supply of inputs and/or equipment, and finally the marketing strategies of "atta" production cowpea-processing microenterprises.

\section{Characteristics of production and sales locations}

"Atta" are often produced in front of the home of the woman who runs the processing microenterprise, near road junctions, or next to public/private institutions (ministries, health centers, schools, university campuses, etc.). The same location is used to sell the

\footnotetext{
${ }^{2}$ Geographers define residential suburbs as usually having comfortable individual houses.

${ }^{3}$ This number of craftswomen was estimated for a population of 2,401,067 inhabitants in the urban area of Cotonou.
} 
product. Nevertheless, some women whose work volume is higher, thanks to high demand, do all their preparation up to frying at home, while frying and sales are done outdoors. The small round or oval "atta" are prepared and served directly at the point of sale while they are still hot.

The criteria for choosing the location vary from one processing microenterprise to another. But the most important criteria are either of the commercial nature of the location (flows of consumers, proximity to a public place) or its organizational position (near the promotor's home, near a mill). Production sites most often take the form of makeshift shelters, consisting of small huts built with improvised materials (sheets, wooden racks, bamboo, etc.). Sometimes, craftswomen simply shelter under umbrellas or sheets that can be folded away at the end of the day. Open retail sites with no shelter at all, where trees and house roof extensions serve as shade for them and their customers fall into this category. The second form includes shelters built of durable materials (cement blocks, sheets of metal, etc.), most often rented or owned shops. This category is no less widespread than the first.

\section{Work organization}

Production systems The surveyed cowpea processing microenterprises are headed by women and employ mainly female labor. Almost all processing steps are manual, except cowpea milling, which is done by independent mills installed in the streets or city markets. "Atta" is always sold together with other local dishes. In this production system, cowpea processing is often a secondary activity. Only $27 \%$ of the surveyed microenterprises considered "atta" production to be their main activity. Selling a range of different food products is a risk reduction strategy, to cope with possible losses in the sale of such a highly perishable product as "atta." Another possible reason is that "atta" is consumed more as a snack and does not require a whole day to prepare. Generally, the product diversification practice aims to offset the impact of sale losses of some products with the profit made from others.

Techniques and strategies of "atta" production and division of labor Generally, the technology used by atta-producing microenterprises comprises artisanal equipment and meticulous know-how that guarantees the quality of the final product. The women interviewed told us they needed between 100 and $200 \mathrm{~min}$ to process $1 \mathrm{~kg}$ of white cowpeas. The time likely depends on the women's know-how and the kind of equipment or tools they use. It is clearly a low-productivity activity with only about 70 pieces of "atta" dough produced from $1 \mathrm{~kg}$ of white cowpea flour. Although the crushing and milling of cowpeas are already mechanized, mixing also requires mechanization to reduce its time which currently represents $30 \%$ of the total "atta" production time. Improved techniques are required to reduce the length of the whole process (Table 2).

Two groups of atta production strategies can be distinguished: organizing operations/ tasks and organizing the workforce. Cowpea processing usually begins in the morning with the tasks required before mixing and frying, which are done where the final product is sold. Sometimes the cowpeas are sorted the day before. Atta are sold between 4 and 6 o'clock in the afternoon. Where preparation takes place depends on the 
microenterprise, such as the distance between the woman's home and the sales location. Generally, "atta" is prepared on the spot, but two variations were observed. The first one is when all operations, except crushing and grinding/milling, are performed at the sales location. This is the case when the women live far from where they produce and sell their atta. The second variation is when the first processing steps, from sorting until soaking of cowpea cotyledons, are performed at home.

"Atta" production microenterprises primarily use family labor. This was the case for $87 \%$ of the surveyed microenterprises. In addition to the woman who heads the microenterprise herself, the family labor force is mostly made up of her own children or those placed under her guardianship.

The socio-economic characteristics of surveyed artisans are presented in the "Socioeconomic characteristics of surveyed women who run the microenterprise" section. The remaining $3 \%$ employs only occasional workers, on average one worker per microenterprise; but some employ up to three workers. These employees are paid daily. They are recruited through recommendations from family, friends, or other social relations with the owner of the microenterprise, the ability to perform kitchen duties, etc.

Finally, the tasks are shared according to the skills and status of each person (worker versus boss; new versus old) in the processing microenterprise. Preparation, for example, is often carried out by the owner. This involves sensitive operations that require great care such as soaking, kneading/mixing, and frying and are done by the owner herself or under her strict supervision if the work requires too much physical effort.

\section{Socio-economic characteristics of surveyed women who run the microenterprise}

Entry into the profession of "atta" production requires basic know-how and is most often acquired from a parent (mother, aunt, guardian, etc.). The process of learning is

Table 2 Duration of cowpea processing steps in artisanal "atta" production

\begin{tabular}{lll}
\hline Steps & Equipment or tools used & $\begin{array}{l}\text { Time required (in minutes) } \\
\text { for } \mathbf{1} \text { kg of cowpeas }\end{array}$ \\
\hline $\begin{array}{lll}\text { Sorting cowpeas } \\
\text { Crushing cowpeas }\end{array}$ & Sieve, plate/bowl/plastic or aluminum tray & $10-20$ \\
$\begin{array}{l}\text { Soaking crushed } \\
\text { cowpeas }\end{array}$ & Mortar, mechanical mill or grinding wheel & $5-30$ \\
Skinning & Plastic or aluminum bowl & $5-10$ \\
Washing of & Plastic or aluminum bowl & $10-15$ \\
cotyledons & Plastic or aluminum bowl & 5 \\
Soaking cotyledons & Plastic or aluminum bowl & $20-30$ \\
Draining & Plastic or aluminum colander, basket & $5-10$ \\
Seasoning & & 5 \\
Milling & Mechanical mill & $5-10$ \\
Mixing & Plastic or aluminum bowl, spatula & $30-60$ \\
Frying & Spoon, skimmer, aluminum pan, coal or fagot stoves or & $10-15$ \\
Draining & litter, gas stoves & 10 \\
$\begin{array}{l}\text { All processing } \\
\text { steps }\end{array}$ & Aluminum strainer, aluminum basket, bowl, or plate & $\mathbf{1 0 0 - 2 0 0}$ \\
\hline
\end{tabular}

Source: Survey results, September to December 2017 
progressive and takes place within the confines of the parent-trainer's processing microenterprise. The current woman artisans started learning the operations when they were very young. It is an informal training process that spans several years during which the youngest acquires skills from experienced craftswomen in her family (Trèche et al. 2002; Soule et al. 2004). Today, there is no other way for these young girls to acquire such skills.

According to the women we interviewed, the main reasons for their entry into that business included the need to have an income-generating activity to avoid unemployment and poverty, the legacy of parent's skills, or the failure of other activities (Fig. 2). Like other artisanal activities in the food sector, the production of "atta" perpetuates an ancestral culinary tradition that is transmitted from generation to generation in West Africa (Konan et al. 2017).

The average age of the surveyed women was $46(\operatorname{std}=9.86)$, giving evidence that the business is not practiced by young people. This state of affairs may be explained by the patience and meticulousness required by the production of "atta." Further, the profit to be made may not be sufficient to attract young women. This hypothesis is confirmed in the "Financial analysis" section on financial performance. Finally, the majority of women (95\%) were married. They had a relatively low level of formal education: $43.3 \%$ had no education, and the remaining $(56.7 \%)$ had only primary education or barely attended secondary school (Table 3). Only 37\% of them had access to credit through formal microfinance institutions (ALIDE, CLCAM, COMUBA, FNM, PADME, PAPME, etc.) or informal institutions (tontines, social groups). They receive no support from public organizations or NGOs. The lack of professional organization and the atomization of the food processing micro-business in Cotonou city make it very difficult to disseminate information and to dialog with the public authorities. Current public policies concerning the sector are non-existent or not effective. Sometimes instead, repressive public measures are implemented, leading to misunderstandings and to the refusal of government development initiatives by very vulnerable populations.

Finally, it is important to note that changes have occurred in the practices of woman artisans over the last 10 years. For example, glass cases that preserve the quality and safety of food are now used. This new practice originates from the Ministry of Health

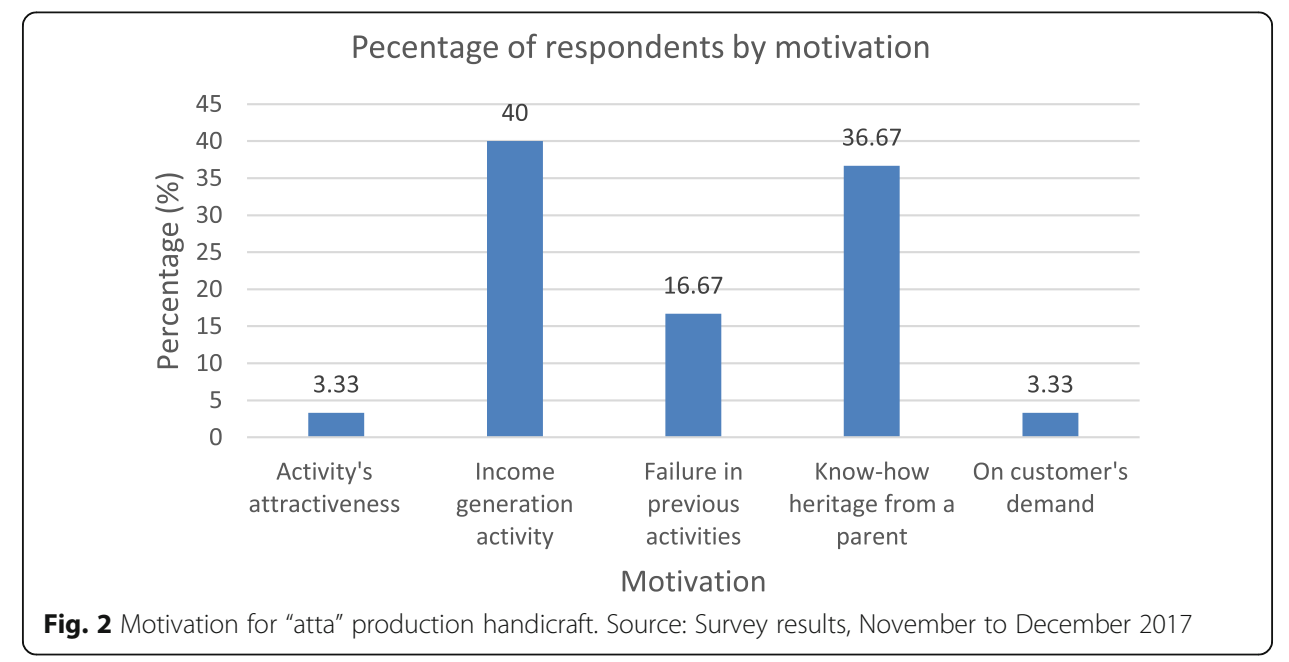


awareness-raising concerning food hygiene. However, most of the artisans surveyed did not use glass cases, hot "atta" dumplings are being purchased by consumers as soon they are fried. Indeed, the glass cases are not well ventilated, which could lead to product deterioration by the end of the day.

\section{Supply of raw materials, equipment, and other consumables}

The supply of raw materials is exclusively organized by the women themselves. The frequency of cowpea supply varies considerably, but $63.33 \%$ of craftswomen preferred several small supplies per week, which they purchased from cowpea retailers in urban markets (Fig. 3). This may be to avoid possible cowpea deterioration and losses during storage. However, the lack of cash/capital for bulk purchase is likely the main reason, as is the case of many petty traders in the city. The quantities of white cowpeas purchased ranged from 5 to $11 \mathrm{~kg}$ per week, giving a total of $292.5 \mathrm{~kg}$ for the 27 surveyed women. Purchasing cowpeas in the market remains advantageous because they benefit from competition, i.e., they can compare prices and pay the best price. Dantokpa is the biggest raw foods market in the country and the main cowpea supply market. More than half the women $(55.17 \%)$ said they bought cowpeas from the same one or two suppliers. This loyalty may be based on a social relationship (friendship, kinship, etc.) between sellers and customers, or emerge gradually after several satisfactory transactions in terms of quality of the product. Despite these relationships, most craftswomen prefer to pay cash for the raw material to avoid accumulating debt and to be able to predict their income. Other consumables (manufactured inputs, packaging materials, fuel, etc.) are also purchased in the market and, to a lesser extent, in the neighborhood. Work equipment and tools are purchased from tradesmen and craftsmen (blacksmiths, carpenters, welders, etc.) in the city.

Table 3 Socio-demographic characteristics of the woman artisans surveyed

\begin{tabular}{llr}
\hline Characteristics & & Values \\
\hline Sex (\%) & Male & 0 \\
Age (years) & Female & 100 \\
& Minimum & 23 \\
& 1st quartile & 40 \\
& 2nd quartile & 46 \\
& 3rd quartile & 52 \\
& Maximum & 63 \\
Level of formal education (\%) & Average & $45.57(9.86)$ \\
& None & 43.33 \\
& Primary & 33.33 \\
Marital status (\%) & Secondary & 23.33 \\
& Married & 95.4 \\
& Divorced/separated & 3.67 \\
Household size & Widowed & 0.93 \\
\hline
\end{tabular}

Standard deviations are in parentheses 


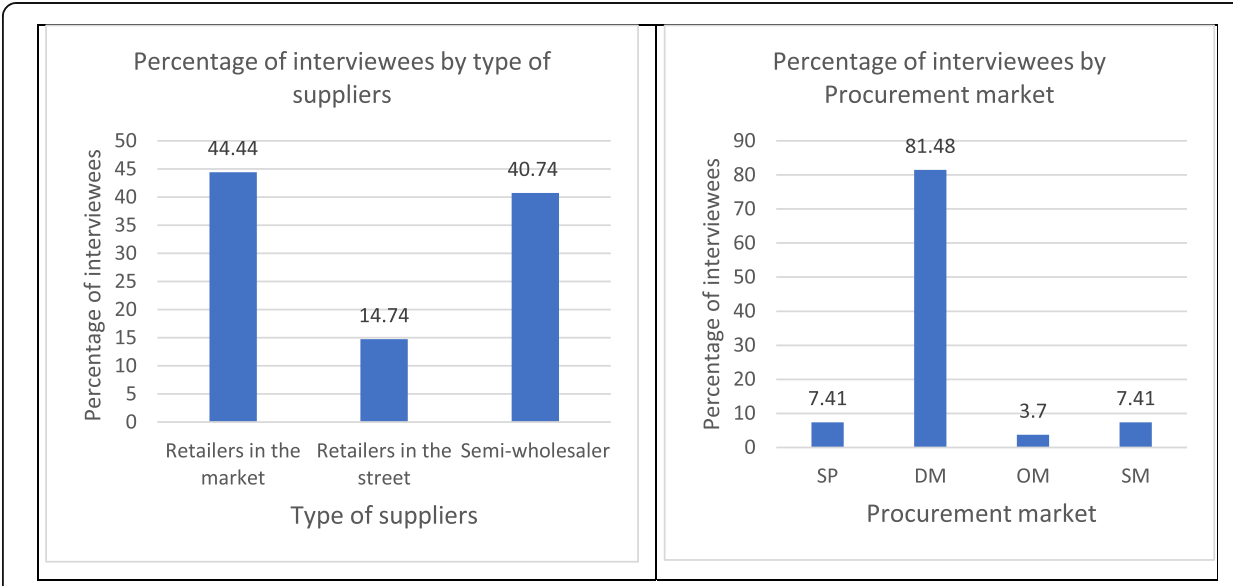

**SP: Self-procurement from cowpea traders, DM: Dantokpa market; OM: Others markets; SM: Street market

Fig. 3 Type of cowpea providers and supply markets. Source: Survey results, November to December 2017

\section{Consumption patterns and distribution and sales strategies}

In Cotonou city, atta (fried dumplings made of cowpeas) are usually consumed together with fermented or unfermented porridges made from corn, sorghum, rice, or corn or wheat pasta (macaroni) and/or associated with other fried products (yams, sweet potatoes, banana fritters called "talé-talé", etc.). These results are consistent with those of N' Bessa (1995) and Agli et al. (2004) who found that in Cotonou, consumers of cowpea atta eat them with yam fries. Eating atta with starchy products is a food habit in southern Benin. Indeed, legumes and other protein-rich food products are often consumed together with cereal- or tuber-derived foods.

Here, we briefly present the marketing strategies of atta producers according to the 4Ps of marketing (product, price, place, promotion). Sales of atta match the above-mentioned food consumption habits. The woman artisans carefully survey the technical process to ensure the processed product tastes good. Obviously, customers want good tasting warm or hot atta. Cowpea dough is fried in small batches. However, if not well controlled, this practice can lead to degradation of dough quality and production losses. Atta are sold on the spot immediately after being fried. Small round or oval atta are sold for 10 FCFA (1.8 cents, US\$) or 25 FCFA (4.5 cents US\$) each, the latter price being the mostly widespread. Extra atta are given for free to customers who purchase a large quantity. Woman artisans who operate in markets like Dantokpa employ itinerant saleswomen who are paid a commission according to the quantity sold. Finally, the product is advertised, with slogans such as "hot atta" and "still hot" launched from time to time to attract potential customers' attention.

The above prices represent $1 / 20$ th of the daily remuneration of family labor in artisanal food processing (less than US $\$ 1 /$ person/day) or $1 / 20$ th of the daily wage of uneducated women employed in occasional domestic housework. It is clear that artisanal production of "atta" is a time-consuming and badly paid business. 


\section{Financial analysis}

\section{Production costs of atta}

The production costs of atta include the costs of raw material and ingredients (chili, garlic, pepper, ginger, salt, oil, etc.), energy (electricity and fuel), family labor and occasionally hired labor, transport of inputs, depreciation of equipment, and external milling service. Across the sample of 27 women surveyed, the average production cost per kilogram of processed white cowpea was 1633.9 FCFA, standard deviation 434.2 CFA (Table 4). This represents the arithmetic mean of the unit cost variable "cost per week/quantity of cowpeas processed in a week," calculated directly for the sample of 27 women. It differs slightly from the ratio (1480.1 FCFA) of the average quantity of cowpea processed in a week per craftswoman $(10.83 \mathrm{~kg})$ to the average cost per week $(16,029.7$ FCFA). The difference is usually due to the unequal number of observations of the top and bottom variables that make up a quotient variable.

Intermediate inputs, i.e., raw material (cowpeas) and ingredients, represent $90.4 \%$ of the total production cost. The raw material alone accounts for $39.1 \%$ and ingredients $23 \%$, making the bulk (62.1\%) of the total cost of production. Indeed, cowpeas are expensive in urban markets, particularly in Cotonou. Family labor ranks fourth among production costs. It is the main workforce used by cowpea-processing microenterprises. However, the overestimation of the use of this workforce was noted during the survey. Therefore, the remuneration of family labor is considered here as a net operating income obtained when the family labor opportunity cost is excluded. Equipment depreciation, occasionally hired labor, and water account together for less than $3 \%$ of total production cost, which attests of the artisanal, poorly equipped nature of the microenterprises.

Table 4 Production costs of atta made from white cowpeas

\begin{tabular}{lrr}
\hline Cost items & $\begin{array}{c}\text { Average cost per kilogram of } \\
\text { processed cowpeas* (FCFA) }\end{array}$ & Percentage \\
\hline Cowpeas (raw material) & $589.8(99.8)$ & 39.1 \\
Ingredients & $412.5(238.7)$ & 23.0 \\
Transport & $57.1(56.5)$ & 3.0 \\
Water & $20.2(19.3)$ & 1.1 \\
Fuel & $108(51.5)$ & 6.3 \\
Packaging & $43.7(20.6)$ & 2.6 \\
Milling & $195.4(26.3)$ & 12.5 \\
Rent & $40.1(105.3)$ & 2.6 \\
Intermediate inputs & $1466.8(372.1)$ & 90.4 \\
Occasionally hired labor & $15(47.7)$ & 1.8 \\
Family labor & $144.8(115.3)$ & 7.5 \\
Depreciation & $7.3(8.8)$ & 0.4 \\
Total cost & $1633.9(434.2)$ & 100.0 \\
Total cost without family labor & $\mathbf{1 3 6 9 . 2}$ & -
\end{tabular}

Source: Survey results, November to December 2017

"This is the arithmetic mean of the unit cost variable "cost per week/quantity of cowpea processed in a week," for the sample of 27 craftswomen. Standard deviations are in parentheses. The average quantity of cowpeas processed in a week by each woman was $10.83 \mathrm{~kg}$, and the average cost per week was $16,029.7$ FCFA 


\section{Financial performance of artisanal "atta" production microenterprises}

The ratio of added value to the cost of intermediate inputs (AV/IC) is 24.6\%, which indicates that 100 FCFA invested by the women in atta production generates about 25 additional FCFA as wealth created. The average profit is 159.4 CFA per kilogram of cowpea and represents $49 \%$ of the wealth created per kilogram of processed cowpea. This corresponds to a return rate of $11.7 \%$ on the total production cost. Knowing that the return on capital in the country's microfinance institutions ranges between 18 and $24 \%$ per year, artisanal production of atta is therefore barely profitable, if all production costs, including family labor opportunity cost, are taken into account. Although access to credit is generally difficult for farmers and for artisanal food processing women in Benin, the above comparison is nevertheless appropriate. Indeed, farmers, woman artisans, and petty traders quite often turn to microfinance institutions for short-term loans, which they get at fairly expensive interest rates of up to $24 \%$ per year. Nevertheless, microfinance institutions are the least harmful, because existing alternatives (intermediaries and loan sharks) are just as expensive, even ruinous. To be considered really profitable in Benin today, the rate of return on the investment in an agricultural or food processing activity should exceed $24 \%$, which is far from the case for atta production.

Hessanon and Sodssinour (2009) found that cassava activities provide producers with an average annual income of 112,605 FCFA at an average annual cost of 78,500 FCFA. The corresponding figures for processors are 635,844 FCFA and 180,421 FCFA. These correspond to return rates of $43.4 \%$ and $252.4 \%$, respectively. However, it is important to note that cassava processing is mechanized, especially milling and pressing, hence the very high return rate. Gandji (2015) estimated the return rate for artisanal palm oil production at $24.7 \%$ and $82.5 \%$ during high production and low production periods, respectively. All these figures show that the profitability (11.7\%) of artisanal atta production is really very low compared to similar microenterprises (Table 5). Agli et al. (2004) already found that artisanal cowpea processing was a low-profitability business. Meanwhile, woman artisans involved in this activity are likely under the illusion of good profitability (27.13\%) as they usually do not include the family labor opportunity cost, self-consumption, and depreciation of processing equipment in their production costs. This return rate is slightly higher than the return rate on capital borrowed from microfinance institutions in the country. This is undoubtedly the reason why atta production is still underway on many street corners in Cotonou. The high demand for this snack continues to drive production despite overall low profitability.

\section{Conclusion}

This study investigated the economic performance of the production of atta (deep-fried cowpea snacks), a high-demand artisanal food processing activity undertaken by lowincome women in Cotonou, Benin. The results showed that the women's microenterprises have a specific structure of their own, a training system anchored in cultural knowledge transmission from mother to daughter (from generation to generation), but an overall low profitability, whether family labor is taken into account or not. These microenterprises seem to have some potential for economic development considering the activity's attractiveness for these women and the early "employment" opportunity for female youth in that stratum of the urban society. However, women involved in artisanal food processing need technological upgrading and business empowerment to 
Table 5 Aggregate operating account of "atta" production from white cowpea

\begin{tabular}{|c|c|c|}
\hline Items & $\begin{array}{l}\text { Average cost per processor } \\
\text { for } 1 \mathrm{~kg} \text { of cowpea (FCFA) }\end{array}$ & Performance indicators \\
\hline Gross revenue $(R)$ & $1793(546)$ & \\
\hline Intermediate inputs cost (IC) & $1466.8(372.1)$ & \\
\hline Total operating cost (TC) & 1643.3 & \\
\hline Operating cost without family labor & 1369.20 & \\
\hline Added value (AV) & & $326.5(488.5)$ \\
\hline Net operating income or profit $(P)$ & & 159.4 (477.7) \\
\hline Net operating income without family labor cost & & 371.48 \\
\hline AV/IC ratio (\%) & & $24.6(0.33)$ \\
\hline Rate of return, $\Omega$ (\%) & & $11.74(0.28)$ \\
\hline Rate of family labor remuneration (\%) & & 27.13 \\
\hline
\end{tabular}

Standard deviations are in parentheses. The main financial performance indicators are in bold $N=27$ artisanal microenterprises

Source: Survey results, November to December 2017

become real entrepreneurs. Indeed, if health risks and nutrition are addressed and local tastes are valued to keep technophile consumers on board, a rapid rise in urban demand for processed food is likely to occur, inasmuch as new technologies bring innovative products to consumers (Coppola and Verneau 2014). In that perspective, the women would need to be able to overcome the key constraints their microenterprises are facing, including low access to credit, no training, and no government recognition. Chiwaula et al. (2018) found similar constraints, especially low resource base, education, and market access, among female solar tent fish dryers in Malawi.

In that respect and considering that Benin's population is today more than $50 \%$ female (most of whom are poor), appropriate policies are needed to take them out of poverty and to create the emerging economy to which the country aspires. In particular, dedicated investment and business development support should be provided to these women to meet the growing domestic urban demand for atta and to envisage in the near future, the export of stabilized and safer cowpea finished products.

\footnotetext{
Abbreviations

AV: Added value; CESAO-PRN: Center for Economic and Social Studies of West Africa - Regional Pole of Niger; CIRA D: International Center of Agronomic Research for Development (France); FAO: Food and Agriculture Organization of the United Nations; FCFA: West Africa French Zone common currency (XOF); IC: Intermediate inputs cost; IFDC: International Fertilizer Development Center; IFPRI: International Food Policy Research Institute; INRAB: National Institute of Agricultural Research of Benin; NOI: Net operating income; OCDE / OECD: Organization for Economic Cooperation and Development; P: Profit; PAPA: Program of Agricultural Policy Analysis in Benin; PRODEX: Project for Export Development in Niger; R: Gross revenue; TC: Total operating cost; UNESCO: UN Education, Science and Culture Organization; $\Omega$ : Rate of return
}

\footnotetext{
Acknowledgements

This article is a product of the socio-economic component of the ICOWPEA (Increasing COwpea value chain sustainability in West Africa through Product and ProcEss innovAtion) research project, jointly implemented by the International Center of Agronomic Research for Development (CIRAD) and the Faculty of Agronomic Sciences of the University of Abomey-Calavi (FSA/UAC). We thank the project's donors, as well as Dr. Aurélien Briffaz, project coordinator, and Professor Djidjoho J. Hounhouigan, the scientific leader of the project.
}

\section{Authors' contributions}

CEK and BGH designed the methodology of the study. CEK organized the data collection and performed the preliminary data analysis and interpretation. BGH coordinated the manuscript write-up and provided policy implications to the study. TF facilitated institutional support for the research and provided insights into the African food processing sector based on his previous experience. All authors participated in the writing and revision of the paper. All authors read and approved the final manuscript. 
Funding

The ICOWPEA project is funded by the Agropolis, Daniel and Nina Carasso, and Cariplo Foundations as part of the

"Thought for Food Initiative" call for projects. This paper thereby benefited from that funding.

\section{Availability of data and materials}

Data used for this study are available at CIRAD, UMR Innovation, Montpellier, France. They can be shared only with the permission of this organization.

\section{Competing interests}

The authors do not have any competing interests in this manuscript.

\section{Author details}

${ }^{1}$ Faculty of Agronomic Sciences, University of Abomey Calavi, 03 BP 2819 Jericho, Cotonou, Benin. ${ }^{2}$ UMR Innovation, CIRAD, Montpellier, France.

Received: 12 December 2018 Accepted: 4 September 2020

Published online: 08 October 2020

\section{References}

Agli CK, Sodjinou E, Singbo AG (2004) Socio-economic diagnosis of the street food sector in Cotonou, FAO, p 90

Allen T, Heinrigs P (2016) Les nouvelles opportunités de l'économie alimentaire ouest-africaine. Notes ouest-africaines, $n^{\circ} 1$, Éditions OCDE, Paris. https://doi.org/10.1787/5jlwjg67l25f-fr

Allen T, Heinrigs P, Heo I (2018) Agriculture, alimentation et emploi en Afrique de l'Ouest. Secrétariat du Club du Sahel et de I'Afrique de l'Ouest. https://amica.hypotheses.org/files/2018/06/Agriculture-alimentation-et-emploi-en-Afrique-de-1\%E2\% 80\%990uest.pdf

Arouna A, Afomasse D (2005) Analysis of the competitiveness of the pineapple industry in Benin. Final Report. National Institute of Agricultural Research of Benin (INRAB)/Program of Agricultural Policy Analysis (PAPA), p 27

Bendech MA (2013) Alimentation de rue à Bamako au Mali : problématique et approches d'intervention. Revue Mali Santé Publique (RMSP) 2013, Tome III, No. 1. http://www.revues.ml/index.php/msp/article/view/1442.

Bergmann D (1985) A propos du "coût d'emploi" de la main-d'oeuvre agricole. Économie rurale, No. 165, pp. 38-39. https://www.persee.fr/doc/ecoru_0013-0559_1985_num_165_1_3127.

Bricas N, Broutin C (2008) Agri-food and trade micro-activities and poverty reduction in sub-Saharan Africa. In: Geneva Trade \& Development Forum "Trade as a development tool: partnerships and policies", September 2008. Crans Montana, p 21

Broutin C, Rouyat J (2008) Qualitative Youth and Adult Education (EQJA): study on women's training in the agri-food sector. In: UNESCO, Research and Technology Analysis Group - Senegal 2008. Final Report, p 92

CESAO-PRN - Center for Economic and Social Studies of West Africa (2009) Baseline study on the cowpea sector in the Zinder region. SNV Zinder, Maradi Antenna, Final Report, p 80

Chiwaula LS, Chirwa GC, Lucy S, Binauli LS, Banda J, Nagoli J (2018) Gender differences in willingness to pay for capitalintensive agricultural technologies: the case of fish solar tent dryers in Malawi. Agric Food Econ 6:1. https://doi.org/10 1186/s40100-018-0096-2

Coulibaly O, Arinloye AD, Faye M, Abdoulaye T, Calle-Goulivas A, Ahoyo R (2014 Analyse des chaînes de valeur régionales du manioc en Afrique de l'Ouest. Etude de cas de la Côte d'Ivoire. CORAF/WECARD et PPAAO/WAAPP. https://www. researchgate.net/publication/26998928_ANALYSE_DES_CHAINES_DE_VALEUR_REGIONALES_DU_MANIOC_CAS_DE_LA_ COTED\%27IVOIRE.

Coppola A, Verneau F (2014) An empirical analysis on technophobia/technophilia in consumer market segmentation. Agric Food Econ 2:2 http://www.agrifoodecon.com/content/2/1/2

Doka IA (2010) Operational action plan of Niger's Niébé sector. Final report. PRODEX, Republic of Niger, p 92

Dossou SAR, Aoudji AKN, Adegbidi A (2017) Processing of local agricultural products to meet urban demand: lessons from soybean cheese consumption analysis in Southern Benin. Afr J Market Manag 9(8):133-143. https://doi.org/10.5897/ AJMM2017.0541

Fabre P (1994) General methodology note on value chain analysis. Training Paper for Agricultural Planning No. 35. Agricultural Policy Support Service, Division of Policy Assistance, FAO, Rome

FAO (1997) L'alimentation de rue en Afrique. Revue «Aliments dans les Villes »; DT/25-97F - 1997. FAO, Rome, p 12

Gandji B (2015) Analyse comparative des types d'exploitations de production d'huile de palme dans la commune de Sakété au Bénin. Mémoire de Licence, Faculté des Sciences Agronomiques, Université d'Abomey-Calavi, Benin.

Hessanon GC, Sodssinour T (2009) Impacts de la culture du manioc sur le développement socioéconomique de la commune rurale d'lkpinlè. Faculté des Sciences Economuques et de Gestion. Université d'Abomey-Calavi, Bénin

Honfoga BG, N'tandou-Bonzitou G, Vodouhè SR, Bellon RM, Hounhouigan JD (2018) Assessing the role of market integration in the consumption of traditional foods in Benin: a joint price instability coefficient and diet composition approach. Agric Food Econ 6:2. https://doi.org/10.1186/s40100-018-0097-1

Honfoga BG, Ohanete JS, Tevi CD, Sedegnan COA, Ogounchi M-R (2019) Assessing food attributes and marketing services of private restaurants on the campus of University of Abomey-Calavi, Benin. Afr J Market Manag 11(2):10-20. https://doi.org/ 10.5897/AJMM2018.0588

Konan AS, Yeboue KTSU, Kouassi K, Assi-Kaudjhis JP (2017) Structuration de l'espace liée à la production de l'attiéké dans la commune de Cocody (district d'Abidjan). Revue Ivoirienne de Géographie des Savanes, Numéro 2 Juin 2017, ISSN 25212125, pp 77-92.

Madode YE (2012) Keeping local foods on the menu: a study on the small-scale processing of cowpea. PhD Thesis, Wageningen University, Wageningen, The Netherlands (2012), 176p.

Madode YE, Houssou PA, Linnemann AR, Hounhouigan DJ, Nout MJR, Van Boekel MAJS (2011) Preparation, consumption and nutritional composition of West African dishes. Ecol Food Nutr 50(2):155-136 
Mayer and Glabe (2008) Alguito para ganar (a little something to earn): Profits and losses in peasant economies. American Ethnologist 26(2):344 - 369. doi.https://doi.org/10.1525/ae.1999.26.2.344.

N'Bessa B (1995) Les repas de rue à Cotonou. Les Cahiers d'Outre-Mer Année 1995 48-192 pp. 552-555. https://www.persee. fr/doc/caoum_0373-5834_1995_num_48_192_3586.

Reardon T (2015) The hidden middle: the quiet revolution in the midstream of agri-food value chains in developing countries. Oxf Rev Econ Policy, vol. 31, n 1, pp. 45-63, doi.https://doi.org/10.1093/oxrep/grv011

Robinson E, Nwuneli N, Henson S, Humphrey J (2014) Mapping value chains for nutrient-dense foods in Nigeria. Reducing Hunger and Undernutrition, Institute of Development Studies, Evidence Report N 65, p 94

Soule BG, Bello R, Orou BMA, Gibigaye M (2004) Artisanat alimentaire, sécurité alimentaire et lutte contre la pauvreté en Afrique : le cas du Bénin. Laboratoire d'Analyse Régionale et d'Expertise Sociale (LARES), Cotonou, p 83

Staatz J, Hollinger F (2016) West African food systems and changing consumer demands. Notes ouest-africaines, $n^{\circ} 4$, Éditions OCDE, Paris, 26p. doi.https://doi.org/10.1787/b165522b-en.

Trèche S, Den Hartog AP, Nout RMJ, Traoré A (2002) Les petites industries agroalimentaires en Afrique de I'Ouest : Situation actuelle et perspectives pour une alimentation saine. Cahiers Agric 11:343-348

Tshibaka BT (1989) Food production in a land-surplus, labor scarce economy: the Zairian basin. International Food Policy Research Institute. IFPRI Research Report No. 74, International Food Policy Research Institute, Washington DC, USA.

Tshibaka BT, Honfoga BG, Têvi J, Houngbo A. \& Dokoué J (1992) Facteurs déterminant la connaissance, I'adoption, la diffusion et les effets des techniques culturales modernes et des engrais au Sud-Est du Togo. Rapport du Projet "Fertilizer Policy Research Project", IFPRI/IFDC, Lomé, Togo.

Yabi et al (2014) Impact of adoption of semi-mechanized technologies of shea butter processing on rural women's income in Northern Benin (West Africa). J Dev Agric Econ 6(6):249-256. https://doi.org/10.5897/JDAE12.123

\section{Publisher's Note}

Springer Nature remains neutral with regard to jurisdictional claims in published maps and institutional affiliations.

\section{Submit your manuscript to a SpringerOpen ${ }^{\circ}$ journal and benefit from:}

- Convenient online submission

- Rigorous peer review

- Open access: articles freely available online

- High visibility within the field

- Retaining the copyright to your article

Submit your next manuscript at $\boldsymbol{\nabla}$ springeropen.com 